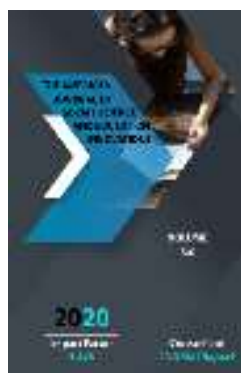

\title{
Improving The Methodological Training Of Future Chemistry Teachers To Work With Talented Students
}

\author{
Ismailov Saidjon Azamjonovich \\ Senior Teacher, Department Of Methods Of Teaching Chemistry, Faculty Of Natural Science, \\ TSPU Named After Nizami, Uzbekistan
}

Journal Website: http://usajournalshub.c om/index,php/tajssei

Copyright: Original content from this work may be used under the terms of the creative commons attributes 4.0 licence.

\section{ABSTRACT}

The article describes the characteristics of develop and improve future chemistry teachers working methodological preparation with intellectual pupils, their advantages and disadvantages, types of methods and use. Therefore, how to work, future chemistry teachers with talented students during the lesson principles are given.In addition, the works of scientists in this field, their conclusions and recommendations are given.

\section{KEYWORDS}

Chemistry, methodology, science development, self-education, method of teaching, self-evaluation, modern innovative technology, instructional materials, science subjects, 3D visualization.

\section{INTRODUCTION}

As President Sh.M.Mirziyoyev said that, "The young are foudation of our future". Thus, "We will mobilize all the forces and opportunities of our state and society for the development of our young people, who have high intellectual and spiritual potential for independent thinking, to become human beings who are equal to their peers in any field in the world, to be happy [1.14]".

"The Action Strategy on the five priority areas of development of the Republic of Uzbekistan, adopted on the direct initiative and under the leadership of President Shavkat Mirziyoyev, 
has launched a new stage of development. The practical results, signs and features of this process are clearly visible today in all spheres of our lives, and most importantly, in the consciousness, aspirations and actions of our people. In this sense, it is true to say that the Action Strategy is an important program for a new era of development, which defines the scientific, theoretical, practical and constructive basis of rapid development of Uzbekistan in the face of rapidly changing times [2.3].

Talented students have a range of unique abilities that characterize their learning process: mostly they differ in three key learning aspects: their faster learning pace, increased depth of understanding, and special interests. If talented students are to develop their abilities and potential, and learn optimally in a regular classroom, the teaching must be adjusted to meet their special needs. Chemistry high-school curricula have built-in potential to cater to the special needs of talented students. Chemistry learning entails laboratory work and comprehension of abstract concepts. In the classroom, the interactions between teachers and students are core events that trigger other class events. In the present study, the interactions between teachers and talented students in a regular classroom, which are specific for chemistry teaching, were studied. Two general categories of interactions with talented students were found to be unique to the chemistry classroom:

(1) Interactions involving laboratory work and (2) Interactions involving the challenge of teaching chemistry content. We found that since talented students master abstract chemistry concepts quickly and with minimum scaffolding, no interactions regarding this aspect were reported. The present study indicates the essential need for enhancing chemistry teachers' knowledge regarding teaching talented students in the chemistry classroom. [3.172]

MATERIALS AND METHODS
In today's day, a lot of scientific-researches have carried out and been in progress in order to improve results of educational process. Observations have shown that the main attention is paid how to deliver available chemical knowledge which published and demonstrated literatures to anyone and in this area is being achieved excellent results. So that, there are lacks of mastered knowledge which are demonstrating in practice. During explaining properties of elements, mostly inductive teaching gains the main place. It needs to pay attention bellows at teaching elements.

- emanating valency in the generation of molecules;

- Causes of stable and unstable molecules;

- Special position of molecules;

- The state of being hybridization in the formation of molecules;

- -The magnetic properties of the substances, electrical and thermal conductivity, solidity and softness of metals;

- explaining quantum numbers;

- Causes of movements or excited state of electrons in atoms;

- Chemical activity or reactive capability of elements.

On teaching these properties, firstly it creates difficulties for teacher, secondly pupils and students face difficulties to acquire the knowledge. Exactly, this kind of concepts will serve as the foundation of the chemical science. As a matter of fact, in the above mentioned and the meaning of many other properties, there is the basic theory of chemistry "the doctrine of atom structure "and "the theory of chemical connection". There are two theory of chemistry in teaching knowledge and concepts of elements of chemistry.

The formation of components of future chemistry teachers helps to be well educated specialists. Because chemistry teachers who do 
not have components when entering well equipped room, they cannot achieve the result. In today's day, innovational educational technologies which are being invited may not give results.

Therefore, utilizing innovation technologies to learn chemical knowledge in modern way is the main problem of today's.

On the theme "Principles of deductive formation skills of future chemistry teachers in the modernization of the education" theoretical concepts of teaching inorganic chemistry at the scientific research that is being carried out modernization on the basis of informational communication and modern innovation technology. They are carrying the tasks of improvement to teach elements.

As is generally known, nowadays the capacity of scientific knowledge, concepts and imagination is growing rapidly.

This is providing the formational differences of new section and fields, on the other hand, it has destroyed ruling limits and creating integration process.

Due to the fact that, the directions of education "undergoing difficulties" such as the process of differentiation and integration are not able to reflect in education, causing some problems in the system of education. In particular, among the reflecting of education and scientific information comes into breaking.

However, in lower levels of education (school, academic lyceum, colleges) in "space" educational programs " cosmetic repair" the development of scientific and methodological recommendations on individual topics, in some cases, it can be seen them trying to fill by relying on the results of scientific research.

Nowadays, in large numbers of scientists gave ideas, notions, and concepts about how to improve the methodological training of future chemistry teachers to work with talented students:
Mainly the Chemistry deals with atomic and molecular phenomena that can't be observed in higher education. To help students understand these abstract concepts, teachers use analogical models to make concepts more accessible to the learners. The models are more than communication tools; they provide means for exploring, describing and explaining scientific and mathematical ideas; they help to make science relevant and interesting and worth learning. Models should be used with care in teaching and learning because they may expose learners to interpretations that often lead to unexpected alternative conceptions.

Glynn as quoted by Harrison and Treagust, (2000:354) highlighted the need for educators to help learners identify the positive and negative aspects of an analogy. They do not comment on a third and also important aspect of an analogy: the neutral aspect. Hesse (1966) stated that the neutral aspects of an analogy are neither obviously correct nor clearly wrong. These neutral aspects can stimulate new ideas and provide topics for research.

Educators' explanations and learners' mental models interact. How learners interpret these models, depends on the learners' prior experience, knowledge, language skills and thinking strategies (Harrison and Treagust, 2000:355). These authors pointed out that experienced educators recognise, value and encourage these interactions. According to Harrison and Treagust (1998:422), models can only act as aids to memory, explanatory tools and learning devices. Harrison and Treagust (1998:422) also state that educators need to plan the use of models in their lessons. The focus involves pre-lesson planning in which the educator focuses on the concept's difficulty, learners' prior knowledge and ability and the model's familiarity.

According to Ira Ramsen (1846-1927), his memories as a child experiencing a chemical phenomenon as follows: 
While reading a textbook of chemistry, I came upon the statement, nitric acid acts upon copper'... and I [was] determined to see what this meant. Having located some nitric acid... I had only to learn what the words act upon' meant.... In the interest of knowledge I was even willing to sacrifice one of the few copper cents then in my possession. I put one of them on the table; opened the bottle marked nitric acid' poured some of the liquid on the copper; and prepared to make an observation. But what was this wonderful thing which I beheld? The cent was already changed, and it was not a small change either. A greenish blue liquid foamed and fumed over the cent and the table. The air... became colored dark red.... How could I stop this? I tried by picking up the cent and throwing it out of the window... I learned another fact; nitric acid... acts upon fingers. The pain led to another unpremeditated experiment. I drew my fingers across my trousers and discovered nitric acid acts upon trousers... I tell it even now with interest. It was revelation to me. Plainly the only way to learn about such remarkable kinds of action is to see the results, to experiment, to work in the laboratory. (Adopted from Gutman, 1940).[3.175-189]

\section{DISCUSSION AND RESULTS}

Student's knowledge quality assessing is innovative technology of education quality evaluation, which expresses quality of conformance to federal state educational standards. We obtain following results to develop future chemistry teachers working methodological preparation with intellectual pupils:

- Students will be involved in class and outside of class creative practical tasks;

- Students participate in interactive learning;

- Students collaborate and enlarge worldoutlook;
- Students learn through research and search for new information and knowledge;

- It becomes easier to assimilate information to every student;

- Students will be responsible for their teaching.[4.7] 
Doi: https://doi.org/10.37547/tajssei/Volumeo2Issue08-90

The results which students achieve during the experiment it shows this statement:

The content of experimental and control group work

\begin{tabular}{|c|c|c|c|c|c|c|}
\hline № & $\begin{array}{l}\text { Educational } \\
\text { establishment }\end{array}$ & $\begin{array}{c}\text { Experimental } \\
\text { group }\end{array}$ & $\begin{array}{l}\text { Amount of } \\
\text { students }\end{array}$ & $\begin{array}{l}\text { Control } \\
\text { group }\end{array}$ & $\begin{array}{l}\text { Amount of } \\
\text { students }\end{array}$ & $\begin{array}{c}\text { Total } \\
\text { number of } \\
\text { the } \\
\text { students }\end{array}$ \\
\hline & $\begin{array}{c}\text { Tashkent } \\
\text { State } \\
\text { Pedagogical } \\
\text { University }\end{array}$ & 302 & 30 & 301 & 32 & 62 \\
\hline
\end{tabular}

The results of the experimental group checked according to the State Education Standard

\begin{tabular}{|c|c|c|c|c|c|c|c|}
\hline № & Groups & $\begin{array}{c}\text { Amount of } \\
\text { students }\end{array}$ & $86-100 \%$ & $71-85 \%$ & $\begin{array}{c}55- \\
70 \%\end{array}$ & $\begin{array}{c}0- \\
54 \%\end{array}$ & Average \\
\hline 1 & 302 & 30 & 9 & 17 & 5 & - & $86,67 \%$ \\
\hline
\end{tabular}

The results of the control group checked according to the State Education Standard

\begin{tabular}{|c|c|c|c|c|c|c|c|}
\hline № & Groups & $\begin{array}{c}\text { Amount of } \\
\text { students }\end{array}$ & $86-100 \%$ & $71-85 \%$ & $\begin{array}{c}55- \\
70 \%\end{array}$ & $\begin{array}{c}0- \\
54 \%\end{array}$ & Average \\
\hline 1 & 301 & 32 & 5 & 17 & 10 & - & $68,75 \%$ \\
\hline
\end{tabular}

\begin{tabular}{|c|c|c|c|c|}
\hline & \multicolumn{2}{|c|}{ Experimental group } & \multicolumn{2}{c|}{ Control group } \\
\hline Excellent & 9 & $39,00 \%$ & 5 & $37 \%$ \\
\hline Good & 17 & $47,00 \%$ & 17 & $49 \%$ \\
\hline Satisfactory & 5 & $35,00 \%$ & 10 & $42 \%$ \\
\hline
\end{tabular}

\begin{tabular}{|c|c|c|}
\hline Average & $\begin{array}{c}\text { Experimental } \\
\text { group }\end{array}$ & Controlgroup \\
\hline 100 & $86,67 \%$ & $68,75 \%$ \\
\hline
\end{tabular}


Thus, chemistry is one of the hardest subject to teach, because so many different types thinking come into play. To successfully teach it, we need 3D visualization, diagrams, flow charts, modern innovative technologies, foreign chemistry literatures and a history of chemistry lesson.[5.6]

\section{CONCLUSIONS}

In conclusion, Chemistry is a laboratory science and cannot be effectively learned without robust laboratory experiences. Indeed, the identification, manipulation, and general use of laboratory equipment are integral parts of the subject of chemistry. A high school laboratory should have the equipment necessary to conduct meaningful demonstrations and experiments. The physical laboratory environment must be accessible to all students. Teachers must understand that students with limited strength or mobility can have a full laboratory experience with appropriate accommodation, such as a lab assistant. Instruction that is student-centered and emphasizes the role of laboratory demonstrations and experiments is the best method to ensure that students develop these essential skills in science. Thus, good teachers also took strong measures to prevent mean and hurtful behavior like teasing and bullying. Effective teachers know well that when children feel emotionally, as well as, physically safe, they learn far better.

\section{REFERENCES}

1. Shavkat Mirziyoyev. Together we will build a free and prosperous, democratic state of Uzbekistan. Tashkent: Uzbekistan. 2016. -p. 14.

2. Towards Rapid Development and Renewal on the Basis of Action Strategy. Tashkent:
Risola, Gafur Gulom Publishing and Printing House. 2017. - p. 3.

3. Bransford JD, Brown AL, Cocking RR, Eds. (2000). How People Learn: Brain, Mind, Experience, and School. National Academies Press: Washington, DC, pp. 172189

4. M.Nishonov,Sh.Mamajonov,B.Khujaev. Teaching methods of chemistry. Tashkent: Uzbekistan. 2002.-p.7

5. Sh.Mirkomilov,Kh.Omonov, N.G.Rakhmatullaev.Teaching methods of chemistry. Tashkent: Finance and Economy. 2013.-p.6 